
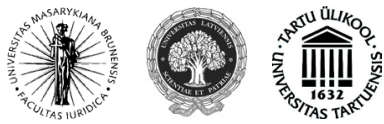

ISSN 2029-2244 (online)

SOCIALINIŲ MOKSLŲ STUDIJOS

SOCIETAL STUDIES

$2014,6(3)$, p. 672-680.

\title{
CONTRASTIVE SEMANTICS AND COMPARATIVE LEGAL TERMINOLOGY
}

\author{
Kristina Juodinytė-Kuznetsova \\ Mykolas Romeris University, Institute of Philosophy and Humanities, \\ Faculty of Politics and Management \\ Ateities str. 20, LT-08303 Vilnius, Lithuania \\ E-mail: krijuodkuz@mruni.eu
}

Received 20 September, 2014; accepted 16 October, 2014

doi:10.13165/SMS-14-6-3-14

\begin{abstract}
The present paper is a contribution to the ongoing discussion on the problem of contrastive semantics and its participation in the process of comparison of legal terminology in different languages. Referring to the concept of contrastive semantics and comparison of legal terms, a question of the reliability of the linguistic tools "adjusted" for comparison arises. The essence of contrastive semantics lies in the definition of the meaning. The structural aspect of contrastive semantics is oriented to the meaning construct, whilst the cognitive aspect - to the real meaning. The real meaning has a subjective character and is actualized in speech acts in different amounts. The aim of this article is to give an overview of the methodology of comparison of legal terms from the standpoint of contrastive semantics covering the problem of structural and cognitive conception of meaning, and the problem of (non-) equivalency of the terms.
\end{abstract}

Keywords: contrastive semantics, comparative legal terminology.

\section{Introduction}

A comparative legal terminology issue has generated a big interest among law and language researchers in the last decades and nowadays comparative analyses

Socialinių mokslų studijos / Societal Studies

(c) Mykolo Romerio universitetas, 2014

(C) Mykolas Romeris University, 2014
ISSN 2029-2244 (online)

http://www.mruni.eu/lt/mokslo_darbai/SMS/ http://www.mruni.eu/en/mokslo_darbai/SMS/ 
of legal documents and discussions on various aspects of legal terms constitute a considerable part of the contrastive semantics issues. As it is difficult to produce parallel terms that are equal in meaning, contrastive semantics offers tools for dealing with the problem of (non-) equivalency of (legal) terms and helps to produce terms that are equal in legal effect.

The article is intended to demonstrate structural and cognitive aspects of contrastive semantics, which are revealed in Part 1, methodology of comparative legal terminology is presented in Part 2, and generalization and insights of the theoretical material are presented in Part 3 (Conclusions).

\section{Structural and Cognitive Aspects of Contrastive Semantics}

The object of contrastive semantics is the research itself of semantics of contrasted languages. Contrastive semantics is oriented towards the content and the plane of expression simultaneously. The content may embrace the naming of one object or the naming of abstraction. Contrastive semantics is inevitably bound to psychological and philosophical cognitive aspects of consciousness. Moreover, it has a very slight boundary between synchronic and diachronic science. Contrastive semantics defines the contrast or comparison as a method that helps to reveal the systems of lexical semantics of different languages, as well as helps to show common and specific features of each language ${ }^{1}$.

Referring to the concept of contrastive semantics and comparison of legal terms, a question of the reliability of the linguistic tools "adjusted" for comparison arises. The essence of contrastive semantics lies in the definition of the meaning. The structural aspect of contrastive semantics is oriented to the meaning construct, whilst the cognitive aspect - to the real meaning. The real meaning has a subjective character and is actualized in speech acts in different amounts. The meaning construct is understood and acknowledged by all speakers as the basis of linguistic communication. This difference relates to the content of comparison. However, three main principles should be followed in each case: comparability, equivalence and neutrality ${ }^{2}$.

Dealing with contrastive semantics, we come across the principle of comparability of legal terms. As we are concerned with the problem of legal terms in several languages, Gudavičius proposes that "compared units have to be described according to the same principles and rules" and "from the scientific standpoint it is not correct to view one language in the mirror of another language because in such case some of its features may remain unnoticed when in the primary language

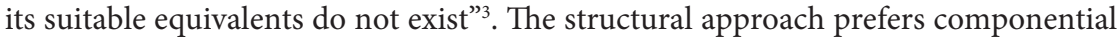
analysis, whereas cognitivists use the system of prototypes.

1 Gudavičius, A. Gretinamoji semantika. Šiauliai: Bibliotheca Actorum, 2007, p. 9-12.

$2 \quad$ Ibid., p. 225.

$3 \quad$ Ibid., p. 217, 226. 
The structural aspect of comparative semasiology (the branch of knowledge that deals with concepts and the terms that represent them) comprises three main levels of comparison: comparison of sememes (equivalency of sememes), of a word (comparison of polysemy, equivalent words of different languages), and of semantic group (internal structure of the semantic group, the meaning of the words and the reflection of the world in them $)^{4}$. The cognitive aspect of contrastive semantics comprises the comparison of concepts. The concept as a mental structure in itself is not the object of semantics; the field of linguistics includes the linguistic expression of the concept, i.e., that part which is expressed by languages ${ }^{5}$. Moreover, the principle of equivalence is related to the principle of neutrality, i.e., dealing with the cognitive system, the semantic systems of languages should not be compared directly one with another, but through a certain tertium comparationis, i.e., the system that is independent of compared languages ${ }^{6}$. It is used to describe the basis of comparison between the languages in terms of a shared criterion, the text-independent meaning. However, the tertium comparationis is considered to be a controversial issue, as it has an inevitable element of subjectivity ${ }^{7}$.

Cognitivists recognize the meaning to appear only during the speaking or writing, whilst structuralists draw a line between the language as a system (French 'langue') and the process of speaking (French 'parole'). Cognitivists use the principle of 'family resemblances'. The members of basic categories are placed around their main member - prototype. The concept of prototype is the key concept in cognitive linguistics. The object that is included in a category has common characteristics with the member of one or another category. This is the essence of the 'family resemblance' principle.

The concept of equivalence is one of the most debated issues in contrastive semantics and especially in comparative legal terminology. If the first term and the second are said to be equivalents, this means that the first one can be used to translate the second and vice versa, without implying that they are identical at the conceptual level. Because of the inherent incongruence of the terminology of different legal systems, natural equivalents of the target legal system that are identical with their source terms at the conceptual level cannot be used, but 'the closest natural equivalent' (the equivalent that most accurately conveys the legal sense of the source term and leads to the desired results) can be chosen? .

4 Gudavičius, A., supra note 1, p. 227-228.

5 Ibid., p. 228-229.

6 Ibid., p. 41-42.

7 Munday, G. Translation Studies. London: Routledge, 2009, p. 231.

8 Mikulskas, R. Kognityvinè lingvistika ir leksikografijos problemos. In: Judžentis, A., sud. Kalba ir žmonès. Vilnius: Vilniaus universitetas, 2009, p. 39-80.

9 Šarčevic, S. New Approach to Legal Translation. The Hague: Kluwen Law International, 2000, p. 234-235 
Maumevičien $\dot{e}^{10}$ discussed the relationship of semantics, cognitive and structural linguistics and emphasized that "the study of meaning within Lithuanian context has been based on the structural conception of meaning with much attention to semantic component analysis. $<\ldots>$ The cognitive conception criticizes the structural one, as structural research on meaning does not provide a full scope of it. Both approaches to meaning within the Lithuanian context do not negate each other; however, no attempts to combine both approaches together have ever been noticed as the structural approach is regarded to be more advantageous. Having examined both structural and cognitive approaches to meaning, it was noticed that both approaches can complement one another and thus provide a more comprehensive view of meaning." After the survey of cognitive and structural aspects, the methodology of comparative (legal) terminology is presented next.

\section{Methodology of Comparative (Legal) Terminology}

This part of the article aims to shed the light on the methodological tools which could be used for comparative research of legal terms. There, the authors deal with the methods and theories that could be applied to analyze (legal) terms and give a general overview of it. Moreover, dealing with the topic of comparative semantics, the authors try not to discern two approaches (structural and cognitive), but strive to find the universal methodology (reviewing the theoretical works of various scholars) that help to analyze the meaning of terms in different languages.

According to Drößiger, the principle of equivalence is something that has to be dealt either at the language level or at the cognitive level. Both directions place the problem of equivalence to different methods. If it is a language equivalence problem, then there are differences between the languages, inevitably a language research has to be conducted. If it is a conceptual problem, i.e., cognitive equivalence problem, then the differences between the conceptual (term) systems of different language and cultural communities are to be analyzed; especially the area of law follows this path of creation of the term or knowledge systems ${ }^{11}$.

Drößiger suggests that the first methodologically correct step before going into the comparison of the term systems of specialized languages is to create term systems (Begriffssysteme) of a single language. The term systems disclosure is probably the actual work of terminologists. Drößiger describes certain steps of the prospective analysis that could be formulated as follows ${ }^{12}$ :

10 Maumevičiené, D. Prototipụ teorija ir semantika. Kalbu studijos. 2010, 17: 18.

11 Drößiger, H. Zum Problem der Terminologisch-Konzeptuellen Äquivalenz Zwischen Zwei Sprach- und Kulturgemeinschaften: die sogenannten "Differenzen" zwischen den Sachen. Kalbotyra. 2007, 57(3): 83-84. 
- Find and compare the characteristic configurations of each term in the term system.

- Find and compare the definitions that help to define the terms.

- Find and create the semantic-cognitive relations between the terms of each term system.

- Find and create the semantic-cognitive relations between the features of each term.

Moreover, Drößiger marks that when analyzing the terms the problem of 'terminological gap' (Begriffslücke) appears that should be paid close attention to. $\mathrm{He}$ suggests that to fill in the language gap, i.e., terminological gap, one has to analyze at first the 'cultural gap' between the compared languages and legal systems. There appears a question of how deep can one analyze legal history, legal tradition, legal systems as well as the jurisprudence of a linguistic and cultural community. Regarding cognitive linguistics, it is about the "creation and discovery" of special semanticcognitive space of the legal system used by certain language and cultural community that contains this specialized, conventionalized and codified knowledge ${ }^{13}$.

It is apparent that most of the scholars that deal with comparison of (legal) terminology come across the problem of equivalence. Šarčevic, Sandrini, de Groot, Gémar, Harrop suggest the functional approach in dealing with the (legal) terms of different languages.

According to Šarčevic, the first step in comparative process is to determine the conceptual characteristics of the source term and qualify them as essential or accidental. Then the process is repeated for the functional equivalent in the target legal system and the final evaluation is conducted by matching up the characteristics of the two terms. One of the methods of comparison that has found widespread support is the functional approach. Since most legal systems provide solutions for basically the same problems, comparative lawyers maintain that concepts and institutions of different legal systems can be meaningfully compared only if they are capable of performing the same task, i.e., if they have the same function ${ }^{14}$. Šarčevic proposes the following categories of equivalence: near equivalence, partial equivalence and non-equivalence, each of which includes both intersection (concepts $\mathrm{A}$ and $\mathrm{B}$ contain not only common characteristics, but also additional ones not shared by the other concept) and inclusion (concept A contains all the characteristics of concept B, plus one or more additional features). Near equivalence is defined, according to the author, when concepts A and B share all of their essential and most of their accidental characteristics (intersection), or when concept A contains all of the characteristics of concept $B$, and concept $B$ all of the essential and most of the accidental characteristics of concept A (inclusion). Partial equivalence occurs when concepts A and B share

13 Drößiger, H., supra note 11.

14 Šarčevic, S. New Approach to Legal Translation. The Hague: Kluwen Law International, 2000, p. 235-236. 
most of their essential and some of their accidental characteristics (intersection), or when concept A contains all of the characteristics of concept B, but concept B only most essential and some of the accidental characteristics of concept A (inclusion). Non-equivalence occurs when only a few or none of the essential features of concepts $A$ and $B$ coincide (intersection), or when concept A contains all of the characteristics of concept $B$, but concept $B$ contains only a few or none of the essential features of concept A (inclusion). Moreover, non-equivalence appears when there is no functional equivalent (exclusion occurs) in the target legal system for a particular source concept ${ }^{15}$.

Sandrini suggests that legal terms are bound by national legal systems, they provide the main information carriers in the text and constitute the basis of their relationships to each other based on the technical and cognitive background of the text. Legal concepts represent the contents of the legal system. Therefore, the linguistic form is always decisively determined by a specific national legal system. There is no German legal terminology, but the terminology of the German legal system ${ }^{16}$.

Sandrini defines equivalency "on the basis of corresponding conceptual features which depend on the intension of the concept and its position in the conceptual system of the chosen subject field" ${ }^{17}$. Offering the methodology of comparison of terms of different stages of comparability, he abandons the concept of equivalency (concept and text based equivalency). He proposes that "after having described the purpose of the single concepts as components of a national legal solution one should move on to see if there are possible connections to concepts of the other national legal system". He states that "legal concepts as part of a national system of laws are fundamentally different across legal systems and that only a comparative approach is possible". The questions which need to be answered in order to find a comparable concept are the following ones: How does the legal system B regulate this matter? (legal setting in B); How is the legal setting structured? (concept system); Is there a concept within this legal setting with the same function or purpose in relation to the overall juridical goal?; What is the position of this concept in relation to the other components of the legal setting? ${ }^{18}$ A methodology by Sandrini suggests the analysis

15 Šarčevic, S. New Approach to Legal Translation. The Hague: Kluwen Law International, 2000, p. 238-239.

16 Sandrini, P. Translation zwischen Kultur und Kommunikation: Der Sonderfall Recht. In: Ubersetzen von Rechtstexten, Fachkommunikation im Spannungsfeld zwischen Rechtsordnung und Sprache. Gunter Narr Verlag Tübingen, 1999, p. 30.

17 Sandrini, P. Comparative Analysis of Legal Terms: Equivalence Revisited. Austria: Universitz of Innsbruck, 2014, p. 5 [interactive]. [accessed on 2014-06-26]. <http://www.researchgate. net/publication/258107454_Comparative_Analysis_of_Legal_Terms_Equivalence_revisited/ file/72e7e526f8c9e49b1d.pdf>.

18 Ibid., p. 5-6 [interactive]. [accessed on 2014-06-26]. <http://www.researchgate. et/publication/258107454_Comparative_Analysis_of_Legal_Terms_Equivalence_revisited/file/72e7 e526f8c9e49b1d.pdf>. 
of "a concept as part of a structure of concepts which has been created for a particular legal purpose. Each concept has to be seen as a component of a legal solution for a particular aspect of real-life". Once all the concepts and their relation to each other (direct, functional, indirect) have been described and documented, the structure of the legal settings emerges clearly. Finally, the role of the single concepts can be compared ${ }^{19}$.

Harrop supports the ideas of Gémar, who recommends the use of functional equivalence for the purpose of the official translation of contracts because it makes the target text both comprehensible to the target reader and faithful to the original source text ${ }^{20}$. When translating from one legal system into another, the differences between those systems have to be taken into consideration. The level of equivalence of terms depends on the extent of relatedness of the legal systems and not of the languages involved ${ }^{21}$.

According to de Groot, it is of primary importance to establish that one legal language must be translated into another legal language. Once one has opted for a particular target language legal system, the meaning in the source language legal system of the terms to be translated must be studied, after which a term with the same content must be sought in the target language legal system. Translators of legal terminology are obliged to practice comparative law ${ }^{22}$.

\section{Conclusion}

Two revised approaches of contrastive semantics offer a broader insight into the process of comparison of (legal) terminology. The methodology of comparison of terminology comprising cognitive and structural approaches could be developed further in the future.

The scholars reviewed in the article are not assigned to cognitive or structural approaches, but they have the common feature: they all agree that concepts or terms

19 Sandrini, P. Comparative Analysis of Legal Terms: Equivalence Revisited. Austria: Universitz of Innsbruck, 2014, p. 7 [interactive]. [accessed on 2014-06-26]. <http://www.researchgate. net/publication/258107454_Comparative_Analysis_of_Legal_Terms_Equivalence_revisited/ file/72e7e526f8c9e49b1d.pdf >.

20 Harrop, J.J. Rek. Polish and English Translation of Jurilinguistic Discourse: Key Aspects and Problem Areas in the Translation of Certain Forms of Legal Contracts in Terms of Terminology Transfer between Two Different Legal Systems: Polish and English [interactive]. [accessed on 2014-06-26]. <http://www.worddocx.com/12034/doc_590.doc>.

21 Ibid., p. 51[interactive]. [accessed on 2014-06-26]. <http://www.worddocx.com/12034/doc_ 590.doc>.

22 De Groot, G.-R., and Van Laer, C.J.P. The Dubious Quality of Legal Dictionaries. 2007, p. 173174 [interactive]. [accessed on 2014-06-26]. <https://www.google.lt/url?sa=t\&rct=j\&q=\&es $\mathrm{rc}=\mathrm{s} \&$ source $=$ web $\& \mathrm{~cd}=1 \& \mathrm{cad}=\mathrm{rja} \& \mathrm{uact}=8 \& \mathrm{ved}=0 \mathrm{CB} 0 \mathrm{QFjAA} \& u r l=\mathrm{http} \% 3 \mathrm{~A} \% 2 \mathrm{~F} \% 2 \mathrm{Farno}$. unimaas.nl\%2Fshow.cgi\%3Ffid\%3D9112\&ei=wbOqU4H8EYboywPi74KgDA\&usg=AFQjCN GzQsVNdn_xx_FOTlZuNJfmDn7Yfw $>$. 
of several languages cannot be analyzed and compared in isolation from the culture, cultural community, legal system and history.

Dealing with comparative legal terminology, we can choose to follow various scholars, but most of the methodology offered by them is bound to the functional approach that help to deal with the problem of (non-) equivalency. As quoted above, concepts of different legal systems can be compared only if they are capable of performing the same task, i.e., if they have the same function (Šarčevic, 2000).

\section{References}

Drößiger, H. Zum Problem der Terminologisch-Konzeptuellen Äquivalenz Zwischen Zwei Sprach- und Kulturgemeinschaften: die sogenannten "Differenzen" zwischen den Sachen. Kalbotyra. 2007, 57(3).

De Groot, G.-R., and Van Laer, C.J.P. The Dubious Quality of Legal Dictionaries. 2007, p. 173-174 [interactive]. [accessed on 2014-06-26]. <https://www.google. lt $/$ url? $\mathrm{sa}=\mathrm{t} \& \mathrm{rct}=\mathrm{j} \& \mathrm{q}=\& \mathrm{esrc}=\mathrm{s} \&$ source $=$ web $\& \mathrm{~cd}=1 \& \mathrm{cad}=\mathrm{rja} \& u a c t=8 \& v e d=0$ CB0QFjAA\&url=http\%3A\%2F\%2Far no.unimaas.nl\%2Fshow.cgi\%3Ffid $\% 3$ D9112\&ei=wbOqU4H8EYboywPi74K gDA\&usg=AFQjCNGzQsVNdn_xx_ FOTlZuNJfmDn7Yfw>.

Gudavičius, A. Gretinamoji semantika. Šiauliai: Bibliotheca Actorum, 2007.

Harrop, J.J. Rek. Polish and English Translation of Jurilinguistic Discourse: Key Aspects and Problem Areas in the Translation of Certain Forms of Legal Contracts in Terms of Terminology Transfer between Two Different Legal Systems: Polish and English [interactive]. [accessed on 2014-06-26]. $<$ http://www.worddocx.com/12034/ doc_590.doc $>$.
Maumevičienè, D. Prototipų teorija ir semantika. Kalbu studijos. 2010, 17.

Mikulskas, R. Kognityvinè lingvistika ir leksikografijos problemos. In: Judžentis, A., sud. Kalba ir žmonès. Vilnius: Vilniaus universitetas, 2009.

Munday, G. Translation Studies. London: Routledge, 2009.

Sandrini, P. Comparative Analysis of Legal Terms: Equivalence Revisited. Austria: Universitz of Innsbruck, p. 5 [interactive]. [accessed on 2014-06-26]. <http://www.researchgate.net/publication/258107454_Comparative_Analysis_of_Legal_Terms_Equivalence_revisited/file/72e7e526f8c9e49b1d. pdf $>$.

Sandrini, P. Translation zwischen Kultur und Kommunikation: Der Sonderfall Recht. In: Ubersetzen von Rechtstexten, Fachkommunikation im Spannungsfeld zwischen Rechtsordnung und Sprache. Gunter Narr Verlag Tübingen, 1999.

Šarčevic, S. New Approach to Legal Translation. The Hague: Kluwen Law International, 2000. 


\title{
GRETINAMOJI SEMANTIKA IR GRETINAMOJI TEISĖS TERMINIJA
}

\author{
Kristina Juodinytė-Kuznetsova \\ Mykolo Romerio universitetas, Lietuva
}

Santrauka. Šiuo straipsniu bandoma apžvelgti gretinamosios semantikos ịtaka analizuojant ir gretinant lietuviu, anglu ir vokiečiu kalbu teisès terminija. Siekiama pateikti metodologines priemones, kuriomis galima gretinti teisés terminus remiantis gretinamaja semantika, skiriant nemenka demesi struktūriniam ir kognityviniam reikšmés pateikimui bei ekvivalentiškumo problemai. Pastaruoju dešimtmečiu gretinamosios teisés terminijos analize domina tiek teisininkus, tiek besidominčius kalbomis asmenis. Ivairūs teisès terminijos gretinimo aspektai analizuojami neatsiejamai nuo gretinamosios semantikos. Ji suteikia priemones, leidžiančias spręsti teisés terminu (ne) ekvivalentiškumo problemas ir padeda surasti terminus, kurie yra tinkami vienai ar kitai teises sistemai.

Reikšminiai žodžiai: gretinamoji semantika, gretinamoji teisès terminija.

Kristina Juodinytė-Kuznetsova, Mykolo Romerio universiteto Politikos ir vadybos fakulteto Filosofijos ir humanistikos instituto lektorè. Mokslinių tyrimų kryptys: anglų kalba, kalbų mokymas, semiotika, gretinamoji semantika.

Kristina Juodinytė-Kuznetsova, Mykolas Romeris University, Institute of Philosophy and Humanities, Faculty of Politics and Management, lecturer. Research interests: English language, language teaching, semiotics, contrastive semantics. 